\title{
"I WOULD LIKE TO SEE THAT ONE IS ABLE TO SAY I'M PROUD OF BEING A CITIZEN OF THE EU..." - THE WAY HUNGARIAN PEOPLE SEE EUROPE AND THE EUROPEAN UNION ${ }^{1}$
}

BORBÁLA GÖNCZ

\begin{abstract}
This paper explores the concepts of Europe, Europeanism and European Union, their meaning to Hungarians, how people define them and how they relate to these concepts through the analysis of qualitative in-depth interviews. The main question is whether the discourse, expressing attitudes towards Europe and the European Union, are of symbolic or utilitarian character. The symbolic way to relate to the EU is based on principles, an ideological or an emotional approach of the subject, while the pragmatic or utilitarian logic is based on rational cost-benefit analysis. The main argument of this current paper is that the way Hungarians tend to relate to the EU is rather utilitarian and it is the utilitarian logic that represents the relevant frame to understand people's attitudes on the subject.
\end{abstract}

KEYwords European Union, Europe, public opinion, Hungary, qualitative research

\section{INTRODUCTION}

Several studies have been conducted about the public opinion about Europe and the European Union in Hungary. These studies were mainly quantitative analyses of survey data. However, as the perception of the European Union (EU) can be considered as new subjects, about which people lack both information and interest according to previous studies, there is a need for a

1 This paper is based on a chapter of the $\mathrm{PhD}$ dissertation of the author. A grant of TÁMOP 4.2.1.B-09/1/KMR-2010-0005 was used for the research.

2 Borbála Göncz is junior researcher at the Corvinus University of Budapest, Institute of Sociology and Social Policy; e-mail address: borbala.goncz@uni-corvinus.hu 
qualitative approach of the question in order to place previous results in their right context.

The main objective of the current paper is to explore the concepts of Europe, Europeanism and European Union, their meaning to Hungarians, how people define and differentiate them. Furthermore, the paper also aims to gain insight about how people relate to the European Union, whether this relationship is of symbolic or utilitarian character and in what discourse they appear. According to previous studies, the distinction between symbolic and pragmatic or utilitarian attitudes towards the EU is a useful distinction when it comes to understanding public opinion on the matter (Lengyel-Göncz $2006,2009,2010)$. The symbolic way to relate to the EU is rather based on principles, an ideological or an emotional approach of the subject, while the pragmatic or utilitarian logic is based on rational cost-benefit analysis. The validity of this distinction is also confirmed by the fact that Hungarian public opinion reveals itself as being attached to Europe over the EU average, which would correspond to a higher level of symbolic attachment, while when evaluating the "good" or "beneficial" character of Hungary's EU membership in a utilitarian way they are among the least Euro-optimists together with British and Latvian people ${ }^{3}$. Despite this fact, the main assertion of this current paper is that the way Hungarians relate to the EU is rather utilitarian and it is the utilitarian logic that represents the correct frame for understanding their attitudes on the subject.

Furthermore, the question whether Hungarians evaluate the European integration process and the place of Hungary within this process in a utilitarian or a symbolic way gained special importance given the recent change in public discourse on the topic of the European Union. While the economic benefits of Hungary's EU membership cannot be ignored, the EU increasingly appears in symbolic discourse, where it is often attributed a negative role ${ }^{4}$. Several studies enhanced the fact that elites and the media play a very important part in shaping public opinion about the topic (e.g. Hooghe-Marks 2005, Bruter 2005), and symbolic interpretation and identification might be something that is activated through the media and elite discourse. Therefore this new trend in public discourse will certainly have an effect on how people see the European Union providing an interesting subject for future research. However, for the purposes of this paper I will present how symbolic and utilitarian elements

3 See Eurobarometer 72, 2009 autumn (http://ec.europa.eu/public_opinion/archives/eb/eb72/ eb72_voll_fr.pdf)

4 See for example Hungary's prime minister Orbán Viktor's speech at the 15th March national holiday event in 2011 (in Hungarian): http:/www.youtube.com/watch?v=n5aSI6fBiIg 
shaped the Hungarian thinking about the topic in 2009 based on 20 in-depth interviews.

The paper will be structured as follows. The first part will summarize the theoretical frame and the main goals of the paper followed by the description of the research design and methodology. Then I will present the results of the in-depth interviews by describing the different definitions of Europe and the European Union, followed by the presentation of the main meta-narratives within which they appear. This rather cognitive approach will be followed by the description of the affective link-identity or how people relate to Europe and the EU. Finally the main findings will be summarized.

\section{THEORETICAL AND EMPIRICAL CONTEXT OF THE QUESTION}

A great number of public opinion researches on the European Union and Europe have a quantitative approach. In these studies several arguments for support of the EU have been elaborated that can be regrouped under three main themes (Hooghe and Marks 2005). People's perception of the European integration process can be subject of a utilitarian or instrumentalist evaluation of its benefits (e.g. Gabel 1998). However, several studies mentioned that the EU project is an abstract and distant one on which people lack both information and interest (e.g. Inglehart 1970), this way their opinion can be less considered as the product of elaborated reasoning. Taking this into account, the approaches based on identity, loyalty, group membership and some kind of affective attachment gain more importance (e.g. Hooghe and Marks 2005). Besides, a third group of explanations of EU support departs from the role of the elites in shaping public opinion or the usage of the domestic political arena as a proxy when people deal with the subject (e.g. Anderson 1998). Regarding the new EU member states with a state-socialist past other specificities, like the effect of the transition or the perception of the market economy and the democratic system are also taken into account when one deals with the subject (e.g. Cichowski 2000, Tucker-Pacek-Berinsky 2002). Furthermore, it has been proven that in these countries utilitarian attitudes towards the European integration process is more salient than in older member states and also has a more individual character (McLaren 2006).

Studies on Hungarian public opinion about the European integration process indeed show that there were great expectations towards the accession with a moderate level of real knowledge (Tardos 2004). Since 2002, however, the enthusiasm towards the EU is in constant decrease and this change might have 
been affected by economic difficulties the country has recently experienced, but also by the low level of trust in political elites and political institutions and the low level of satisfaction with how things are at both the individual and the country level (Lengyel - Göncz 2010). Despite these findings, it is interesting how strongly-above the EU average-Hungarians are attached to Europe.

Because of the mentioned high level of embeddedness of the issue in the domestic political arena, it is important to deal with the role of the media as it plays an important role in determining and channeling the public discourse regarding the European Union. Before the accession, analysing the period between 2000 and 2003 the main discourse presented by the print media were the topics of Hungary's institutional adaptation, agriculture and the question of the Hungarian soil, and the Hungarian ethnic minorities living in the neighboring countries (Vidra 2006). The image of the European Union was rather negative presented as a complex and bureaucratic institution that is challenged by identity-crisis. At the same time the EU also appeared as the defender of certain norms and values, but the subject always appeared in a domestic context. In 2004, at the accession, the media interest towards the question increased also, the EU appeared in the television news more frequently, covering first of all the fact of the accession together with the adoption of legal rules and the funding, followed by the subject of European Parliamentary elections (Terestyéni 2004). Analysing the connection between the conversations that appear in the TV news and the ones that are present in the public opinion, Terestyéni found that as opposed to the media, the public opinion was most interested by the question of agriculture, the Euro and working abroad.

There are a few studies using a qualitative approach that facilitate a deeper understanding of public opinion on the matter. According to a qualitative study within the Eurobarometer (Optem 20015) the EU is often perceived as a distant and an inefficiently working bureaucratic set of institutions, that also represents a threat on the welfare system of the more developped countries. Nevertheless, the EU had a better image among smaller or less developed countries where it stood for economic development and the better representation of the country's interests. However, after the accession, disillusionment in political elites and institutions in Hungary were often projected to the theme of the European Union (Göncz 2009).

Debates on the existence of collective identity at European level or on

5 The study was coordinated by Optem in 2001 covering 15 member states of the EU and 8 candidate countries (the original 10 with the exception of Malta and Lithuania) and Romania and consisted of 4 focus groups within each countries. 
the possible content of a European identity are often based on theories of nation building, state formation and nationalism. The historical or political perspective of national identity argues that different historical contexts induced different patterns of development of nationalism and national identities along the East-West axis. Works dealing with this question enhance democratic participation, citizenship as the basis of nation formation in the Western part of Europe against a more ethnicity-based nationalism in the Eastern part, where the territorial boundaries are playing a less important role than a common ancestor, a common language and common customs (Smith 1991, Delanty 1995). Studies on European identity replicate the mentioned aspects of national identity and are often structured around the civic vs. cultural dimension (e.g. Bruter 2005).

When it comes to post-national identity beyond national level, a question that arises is whether attachments to different territorial levels are complementing each other or competing with each other. There is empirical evidence available for both of these. According to Inglehart's early suggestion (1970) Bruter has found that attachment to national and European levels strengthen each other (Bruter 2005), while Carey (2002) found that the two kinds of attachments are mutually exclusive.

On the other hand identity is multiple and situational, its different constituting elements can strengthen each other, but also be in conflict depending on the context (Smith 1992). Due to this dynamic character of one's personal identity some authors suggest to use the term identification instead of identity (e.g. Isin-Wood 1999). Identity in this understanding appears as a fragmented set of identities where the context and the situation define which fragment of identity is active. They enhance the importance of discursive practices in identity formation; identity is principally a relational concept and is based on the acknowledgment of the other through dialogue, where the individual creates and reproduces its own identification. This is why it is particularly interesting to approach such a subject with a qualitative approach where people are free to express themselves through a personal narrative of their choice.

\section{RESEARCH APPROACH AND METHODOLOGY}

As already mentioned, the main themes addressed in the in-depth interviews were the meaning of the concept of Europe and the European Union, the discourse in which they appear, the personal relations to them and the connection between Europeanness and being Hungarian. The in-depth 
interviews were conducted between December 2008 and May 2009. This was a special period in terms of the EU because due to the world crisis and the coming European Parliamentary elections the subject was increasingly present in the media and the public discourse.

The interviews were of 1-1.5 hours length. The selection of the interviewees were based on the "maximum variation" logic where the aim is to reach a high level variety of the sample according to pre-defined characteristics of the respondents (Patton 1990). In this case the selection was based on gender, age, education, foreign experiences and the place of residence in order to cover a wide range of possible opinions and approaches from either younger and older people, men, women, more and less educated persons with or without foreign experiences living in either Budapest or in a smaller city as these characteristics seemed to have an important impact on opinions on the subject according to previous studies.

The 20 in-depth interviews seemed to be a sufficient and optimal number in order to come to meaningful conclusions on the subject, as towards the end of the fieldwork no new information was given, the content had reached a saturation point (Patton 1990, Seidman 2006, Mason 2002).

The analysis of the interviews was based on the content. When preparing the codes and categories of the analysis an inductive logic was followed and the departure point was the text itself rather than the theory as the main approach was rather explorative than confirmatory (Mason 2002). Below, the results of the cross-sectional analysis of the interviews will be presented. First, the meaning of Europe and the European Union will be described followed by the presentation of the meta-narratives that were used when talking about the subject ${ }^{6}$. One person could use several meta-narratives when expressing his or her opinion. This way, although the main approach for the analysis is a crosssectional one, individual analysis of the interviews will also be used in order to see which meta-narratives are linked and appear together.

In case of the conceptual analysis and the analysis of the meta-narratives it will be also examined whether these are following a utilitarian or a symbolic logic. In this sense, this part of the analysis is of a rather deductive character that aims at to confirm the hypothesis about the utilitarian dominance of the discourse on the European Union and Europe. As previously described, reasoning based on the economic kind of rational cost-benefit analysis,

\footnotetext{
6 Meta-narratives are master narratives or discourses in a wider sense that serve as a context for a person to give a meaning to the events that happen. This way meta-narratives provide a certain frame for interpretation where other narratives (e.g. conceptual narratives) fit placing them in a larger political and economic context (Pahl 1995, p.152).
} 
gathering pros and cons will stand for a pragmatic or utilitarian logic. On the other hand discourses based on principles, culture, history, an ideological or an emotional approach of the subject will be understood as a symbolic way to relate to it. In a way, the analysis of the concepts and the different discourses and argumentation provides the possibility of the analysis of the cognitive elements of the way one relates to Europe and the European Union, while the analysis of identification and attachment covers the affective elements. Nevertheless, these in-depth interviews could have been analysed from many different angles, the one used in this paper is just one of them.

\section{WHAT DO EUROPE AND THE EUROPEAN UNION STAND FOR?}

Not many studies have dealt with the way people define the concepts of Europe and the European Union, how they differentiate between them, how there meanings overlap and how people relate to one or the other (e.g. Janssen 1991, Optem 2001). In this part of the paper the meaning of the two notions will be addressed with the presupposition that people will rather use symbolic discourses when talking about Europe and will have a more utilitarian focus when it comes to the European Union. This presupposition is based on the findings of the Optem research (2001).

However, results did not confirm the presupposition. People seem to abstain from symbolic narratives and the approaches are rather pragmatic and utilitarian even when it comes to the subject of Europe. Although Europe and the European Union is often mixed up and used as synonyms, if excplicitly asked to, people can attribute different meanings to them. The following interview extract is an example for the case where no difference is made.

„, Telling the truth, I think that the two are the same. Europe and the European Union became nearly the same things... Because nearly every country has joined. A few countries are still missing, but it is not that much anymore that we are not helping each other. I think that now everyone is trying to help the others. Those who don't need help nowadays are Russia, China and Japan I think.." (41 year old woman with primary education)

When a difference is made between the two concepts, the EU usually appears as an economic entity with common goals, common issues, that it is something that was artificially created and its existence has a clear starting point. Europe on the other hand usually appears as a geographical entity, a set 
of different countries and is fragmented into different cultures being multicoloured and exists by nature. This way the European Union, often referred to as the "Union", stands for unity, while Europe stands for diversity.

„,Well, the European Union is an economic association, no matter how we look at it, it is the common market that changed its name and became European Union, and that's all... Europe is a colourful alliance of different countries, many countries, many people, French, German, British, Swiss, whatever, where the traditions are different, the culture is different, they live differently, while they are economically bound to each other. Europe is the colourful part and the Union means the economic association." (58 year old man with university education)

Europe mostly appears within a geographical context in the interviews without any attributed symbolic meaning. The conception of Europe as a set of countries often present Europe as a fragmented entity with different cultures, enhancing the inner differences, the cultural diversity with explicit references to certain countries. Besides the geographical context and its conception as a set of different countries, Europe sometimes also appears in an international comparison, as being different from others in terms of values, lifestyle and standard of living. A clear conception of Europe often needs an outgroup or outside of Europe experience. As a continent, it is often compared to other continents, mostly with the USA, appearing as geographical entity, and Asia. Regarding the USA the comparison is sometimes understood in the context of an economic competition when Europe or the EU appears as a counterpart for the USA, the base for differentation of some kind of Europeanness.

Sometimes there were also allusions to the special history of Europe. Interestingly, among the historical references, former empires were often mentioned (e.g. the Habsburg Monarchy) as a reference or as a basis for comparison for the European Union.

The European Union was rather approached through its advantages and disadvantages that show a strong utilitarian character of the attitudes. Among its advantages the collapse of the borders, the possibility to travel, to study and to work abroad, the higher wages, the Euro, the mutual help and the possibility of economic development were mentioned. Others on the other hand were rather pointing out the disadvantages of the European Union such as opening up the markets and the Euro that also appeared with negative connotations, the tendency for over-regulation and the situation of Hungarian agriculture. Interviewees could usually mention more advantages than disadvantages; however, they rather appeared in conjunction. There was also a tendency to 
make a distinction of one's private and professional life when talking about the meaning of the European Union as different effects were mentioned in these two contexts.

,When all this happened [the accession] we were really glad about it at my company because we could get rid of a lot of unnecessary things that we had to do before like the customs and others, so within the EU you can deliver whereever you want if you have a product. We found this a good thing. It is good that one can travel, one is not closed up, and it is also good for you if you are young, after finishing school go and see the world, experience how things are in other countries, then come home and make the same but better. This is a great advantage of it, and I can make a difference because before you were stopped only by approaching the border and asked where you go, and now you can go anywhere. This is a great advantage. As a disadvantage... that these regulations don't make a difference, while in real life they are still making a difference... as I already told there shouldn't be discrimination, but still when it comes to the evaluation of a public procurement it is often not fair..." (58 year old man with university education)

At the same time, interviewees often mentioned that the EU has no direct consequences on their personal life, that it is "invisible" for them. The distinction between one's personal and professional life came up in this respect too, as the EU may be present professionally, but it has still not effect on their personal life. This raises the question of democratic deficit and the problem of lack of knowledge and interest of the citizens, and also that in order to understand such a complex and bureaucratic entity certain cognitive mobilization capacities are indeed needed. These concerns often appear in the context of a "don't know/ I am not knowledgeable about it" discourse.

„My problem with the EU is that I don't see the channel on which I can get there. Without a diploma in law or economy... how would I say, without knowing about paragraphs, what I would like to... I would like that the roof don't hang above the street so that there is no stone falling down and no one would be hurt. But I can't tell this without knowing 46 paragraphs from the construction law or I don't know and from this point the thing is dead. In my opinion many things should be brought closer to the everyday life." (40-49 year old man with university education)

It is interesting how in spite of the lack of information and interest, in some cases interwiewees, usually the more educated ones, held argumentation that 
are also present in scientific discourses that addressed the structure of the EU, the role of the member states and a possibly more centralized institutional design. Among the more federalistic approaches, the USA appeared as the example to be followed in order to achieve a United States of Europe.

Table 1: Number of interviews where the different meanings of Europe and the European Union are mentioned

\begin{tabular}{|c|c|c|c|}
\hline \multicolumn{2}{|l|}{ Europe } & \multicolumn{2}{|l|}{ European Union } \\
\hline Compared to other regions (differences) & 14 & Advantages & 17 \\
\hline Geographical bounderies & 12 & Disadvantages & 9 \\
\hline Cultural diversity & 6 & Travelling & 18 \\
\hline Historical Europe & 6 & Euro & 16 \\
\hline Europe $=\mathrm{EU}$ & 5 & Enforce interests & 11 \\
\hline European values & 3 & No boundaries & 11 \\
\hline & & Development (investments) & 9 \\
\hline & & Work opportunity & 8 \\
\hline & & $\begin{array}{l}\text { European Parliament/ civic } \\
\text { participation/democratic deficit }\end{array}$ & 6 \\
\hline & & Agriculture & 6 \\
\hline & & Higher wage & 6 \\
\hline & & Study abroad & 4 \\
\hline & & Federalism vs. intergovernmentalism & 4 \\
\hline & & Mutual help & 3 \\
\hline
\end{tabular}

Table 1 summarizes the number of interviews where the different meanings of Europe and European Union come up. It can be seen that Europe is mostly understood as a geographical entity, a continent compared to other regions. Europe appears as a geographical entity on the one hand and representing cultural diversity on the other hand - often both meanings are attributed to it by the same person. Overall, when looking at the different meaning one can attribute to Europe and the European Union it can be said that the approach to both concepts is rather utilitarian and pragmatic and there are only a few symbolic discourses. Europe appears in geographical terms and there are some symbolic elements when dealing with its fragmented and multi-faceted, multicultural nature, European Union is very much apprehended through its advantages and disadvantages. Interestingly, there were more discourses about the European Union, the attributed contents were richer in this case than in the case of Europe. This fact could be perhaps drawn back to the role of the media and how the topic was thematized in the public discourses where the European Union must have been an issue dealt with in a much greater number and under a different aspect than Europe. Furthermore, the two concepts are 
often used as synonyms, but only in the case of the European Union where it is often referred to as Europe and not vice versa.

\section{META-NARRATIVES ABOUT EUROPE AND THE EUROPEAN UNION}

After the presentation of the conceptual frame, the meaning of Europe and the European Union, in this part an overview will be given about the typical narrative context in which these concepts appear. Overall, based on the interwiews it can be said that the topic was a difficult one for the respondents, and it was often the first time that they had to formulate an opinion on Europe or the European Union. In this respect the relevance of those previous studies that enhance the role of "proxies", the usage of references about which one has sufficient knowledge, when analyzing the attitudes towards the European Union seem to be confirmed. The domestic political arena can serve as such a proxy (Anderson 1998, Gabel 1998, Hooghe-Marks 2005). Several interviewees mentioned that this topic is very much of political character, and this way the attitudes towards politics and the current political elite naturally came up during the interviews.

Besides the political embeddedness of the topic, the question of the world economic crisis also came up frequently. This is not surprising, however, as the period when the interviews were conducted was the period when the international crisis and its effect on Hungary appeared in the public discourse and the media. Besides the usage of proxies, the fact that opinions and argumentation about the European Union are often not consistent or even contradictory also shows that opinions on the matter are not well-grounded. Sometimes, despite the cited positive experiences with the European Union one might be explicitly Euroskeptic due to the disappointment in Hungarian political and economic performance.

On the one hand there is a very pragmatic approach of the subject, citing advantages and disadvantages, evaluating expectations and their realization. In this case the idea of the European Union is not rejected, although disappointment in the accession is frequently mentioned. In case of more enthusiastic or positive opinions fewer concrete arguments are mentioned representing a more general attitude. This is often paired with "don't know/ I have not enough knowledge" narratives or a symbolic approach where concrete arguments are also missing.

In the following paragraphs the main meta-narratives about Europe and the EU will be presented. The concepts of Europe and the European Union 
will not be differentiated as, according to what has been said earlier, they usually appear as synonyms in the interviews and "European Union" is often replaced by "Europe". These narratives can be regrouped around five main themes. Part of them is centered on the economy, others have an East-West approach to the EU. A third group is formed by the narratives that are based on the disappointment with the country's political performance. A fourth group sees the European integration project through a Hungarian nationalistic discourse. Finally, a part of the narratives focuses on the process of Hungary's accession to the EU, the expectations and the eventual disappointment on the non-realization of these. These different narratives are often interlinked and one person could use several meta-narratives when expressing her opinion.

The following parts of the paper describe these meta-narratives and will be analyzed according to the main standing on the EU they represent. A person's main standing on Hungary's accession to the EU could be positive or enthusiastic, negative or disappointed and perceiving it as a necessary thing. Besides, the meta-narratives will also be classified based on their utilitarian or symbolic character.

\section{a. Economic approaches}

References to the world crisis were present in nearly all interviews. Approaching the subject of the European Union through this angle the EU appeared on the one hand in a helping, supporting role, and on the other hand as a moderator in internal political decisions. This way, this narrative is clearly utilitarian while the perception of the EU in this context can either be positive or negative.

The world financial crisis and the globalization are closely related, and besides the world crisis narrative there is a globalization narrative too. In this case however, the reference is not the domestic political and economic arena as in the previous case, but the international context, the economic process of globalization in general. In this respect it is interesting how the EU can appear as an intermediate level between the national level and the globalized economy with different degrees of importance attached, but it can also be equated to the globalization process. Globalization usually appears through transnational economic processes, the international circulation of capital or the international companies. This narrative is also a utilitarian one, but does usually not involve any positive or negative evaluation of the EU.

In a special case of the economic narratives the EU has a rather negative connotation and Hungary appears as a passive victim of the accession. The 
attitudes implied in this narrative range from the mere formulation of the problem to disappointment, but this is the only narrative characterized by the thought of "the EU was the one that needed us" and not the opposite. Due to its economic argumentation this narrative best fits into the utilitarian logic.

„In my opinion... I don't know, now that the markets are open... what are the advantages and disadvantages of it. It is good for the companies, for west-european companies, it is obvious that it was not by chance they let us join the EU. So they could expand here even more. They are bringing their stuff here more and more. And it's good. For them... I think that it did good to German, French companies, for the big ones economically, it is certain that it did them good that they could exploit Eastern Europe... but I really don't know whether it was good for us?" (27 year old woman with university education)

\section{b. East-West dichotomy}

Contrasting the eastern and the western part of Europe is a narrative where, besides economic differences, differences in values and attitudes are addressed. In both cases the differences define a hierarchical order where the western part represents an example to follow for the eastern part. Often there are references to history and the state-socialist past. The European Union appears in this context in a helping, supporting role in order to "raise" these less developed countries to her level.

,The EU should play a role in making the different countries accept her own regulation, these countries like Hungary and Romania should be forced to accept them, to adopt them and respect them. Because after a while these new rules will make the people change if they have to respect them. And if they don't that should be sanctioned. Do you understand? Because if they can do anything... legal rules are fine, but I can interpret it as I want and still do whatever I want. [...] We are not going to be European citizens until we are doing whatever we want and we don't pay attention to the expectations in lifestyle and others... Because there are expectations. For those who are more developed to be European citizens. I think for example that Great Britain and the Netherlands are like that, that they are far ahead. Although Great Britain is beginning to fall back a little... in enforcing values that are already 
settled there. Because, all right, they are going to keep the monarchy and won't totally change, but there are values, political correctness, efforts against discimination that they were far ahead of us ten years ago. And things have changed in the heads. There you can't make a sexist comment such as a little boy shouldn't wear a pink jumper or something like that. You would have been kicked out for such a comment. You couldn't say something like that. So the changes are in the heads and it still didn't happen in Hungary. But we are EU members just for a few years, how many, four years only. This is the fifth year. This is not enough time to make changes in the heads. And until then... if you can't take over those values that should characterize such a big family as the Union or Europeanness, it is not happening." (50 year old woman with university education)

Using this narrative the interviewees usually try to keep a distance and they try to dissociate themselves from the underdeveloped East, or, in case they associate themselves and use a "we" discourse, it is paired with a detectable feeling of inferiority compared to the West. This finding is in line with the theory of Attila Melegh about the East-West slope where identities are hierarchically organised along this slope (Melegh 2006).

At the same time this narrative doesn't only stand for a unidirectional relationship where the Eastern part of Europe catches up with the Western part. The direction also appears in a reversed way when one mentions the negative effects of the "East" appearing in the "West". There are often allusions to the Balkans with a very negative connotation referring to individual values, way of thinking, attitudes and behaviors in an East-West comparison, as something that should be avoided. The term "Balkan" typically appears as an attribute and not as geographical unit.

This way, the East-West narratives show a positive attitude towards the European Union that embodies the developed West. Besides, these narratives draw the attention on a European fracture. As it is not uniquely based on economic arguments pointing out value and attitude differences besides the economic ones, attaching a hierarchical order to it, this narrative can be rather considered as a symbolic one. Nevertheless, those who have used this metanarrative to express their thoughts on the matter were also more likely to see Europe as a geographical entity. 


\section{c. Hungarian discourse}

The Hungarian nationalistic meta-narrative was a typical discourse when the question of the European Union came up. This narrative is much less utilitarian than the ones previously mentioned. References are made to Hungarian history, national pride and several aspects of national identity, and it has a rather symbolic character trying to place Hungary within the European Union in this respect.

„The other thing is the history, that while Hungarians were fighting the Turks, the Habsburgs, everyone, those who were living in the West were pretty well and occupied with their colonization. They were doing pretty well... there were wars too of course, but not of the kind we had here, not that long, like the Mongol invasion, or the Turks, or even the Habsburg oppression. Maybe I'm a little nasty, but Hungary could have had a little compensation, or at least some acknowledgement, some attention about that we have stopped the invasions... Hungary is in the middle of Europe and all invasions went through its territory as it is geographically in the middle, and we have put a lot of energy into this. To defend Europe was not the primary aim, all right, but to defend ourselves, but through this Europe has also been saved. Now, I don't know how much they know about this in Europe... it is sure that the Hungarian mind, the Hungarian brain is much more than it can be seen today. I'm not talking about the number of Nobel prizes or the great explorers in the past, but the situation in 2009. I think that there is much more, more possibilities in this country than it can be seen, but something is not working. Now I don't know if it is the government's fault or the Union's fault, or it is not a fault of anyone... I don't see it through. But it is certainly a big negative change that people are bound and can't look ahead because of the lack of money. This was my problem too until I went on working in cruisers, that I faced a wall, I worked but there was still no money." (35 year old man with secondary education)

As opposed to the narratives centered around Western superiority this narrative enhances equality and is very much emotionally driven. The discourses about Europeanness, being Hungarian, the relation to the EU that will be described later are all linked with this narrative. However, it is not clear whether this narrative promotes positive or negative attitudes towards the EU - both are present. 


\section{d. Evaluation of the domestic political arena}

The European Union can also appear in a narrative based on the disappointment with the Hungarian political elite, the corruption and the domestic political arena in general. These narratives also imply that the person is disappointed with the European Union too. The usage of the domestic political arena as a "proxy" for the formulation of an opinion is usually used because of the lack of information on such a complex topic as the European Union (Anderson 1998) which requires certain cognitive mobilization capacities (Inglehart 1970) to understand it. Indeed this narrative is rather held by interviewees with lower education and lower level of knowledge and interest in the topic.

„I went [to the referendum on EU accession], alone. The others from my family didn't come because of their disappointment. Unfortunately. But I still went because I felt that I had to. I have a right to vote, so I have to go. And I voted yes, I thought that it would be good for us. At the same time I think that with this European Union it could be good for us, or better for us... but it isn't. Because our government here in Hungary doesn't make us, the people, feel that it was worth for us to join. So I am disappointed in this too. I am disappointed that we became member of the Union." (50-59 year old man with technical education)

These narratives are rather symbolic as the disappointment in the political elite is projected to the European Union. At the same time there are economic arguments too when talking about EU funding disappearing because of corruption, and when Hungary cannot benefit from all the advantages the EU could provide because of the inadequate way the elite represents the country's interest.

\section{e. Perception of accession}

Besides the positive and negative attitudes towards the EU there were those opinions that enhanced the necessary character of Hungary's EU accession. Part of those who saw the EU from this perspective also highlighted the need to belong somewhere and the role of a community. These narratives are usually based on a pragmatic perspective justified by arguments such as Hungary is a "small country" and that "it didn't have a choice" to do otherwise. A clearly utilitarian evaluation of the accession is present in the narratives that enhance 
the fact that Hungary was not prepared for the accession that came too early due to the very low economic development. These narratives also mention the lack of proper representation of Hungarian interests.

As this narrative uses economic arguments to prove that Hungary did not benefit from joining the EU or did not benefit enough, the evaluation of the accession follows a utilitarian logic. In terms of the attitudes towards the EU this narrative can represent both positive attitudes or disappointment but a with very pragmatic approach in any case.

Hungary's accession can, however, be perceived through a symbolic angle. Meta-narratives focusing on the last two waves of the enlargement of the EU are a mixture of utilitarian and symbolic discourses. Despite using a utilitarian argumentation there is still a disappointment with rather symbolic roots about the EU having lost its exclusive character by its massive expansion with postsocialist countries.

„The EU has suddenly grown and starts to burst out like a balloon. I don't know, I was optimistic at the beginning, but then there was a rupture when there was the first plan that Poland, the Czech Republic and Hungary would first join because they were the most economically developed countries. And then something happened and suddenly 10 countries joined and I don't know what was in the background, the real reasons, as we were the most developed and those other countries were just added to us, or added to the EU. So I have this feeling of uncertainty..." (35 year old man with secondary education)

This way this meta-narrative both contain utilitarian and symbolic elements and represent a pragmatic or disappointed attitude towards the European Union.

Table 2 includes the previously described meta-narratives, the number of interviews they appear in, and to what extent they represent a utilitarian or symbolic approach to the subject. The interviews can also be categorized in terms of the main stance the interwiewee had towards the EU. The enthusiastic or positive attitudes often appeared together with a pragmatic or a "don't know" kind of approach and the number of pure symbolic narratives were also very few. It can be seen from the table that several meta-narratives involved both utilitarian and symbolic elements, but still the number of the purely utilitarian narratives (4) exceeded the number of purely symbolic narratives (2).

These meta-narratives, however, were often interlinked ${ }^{7}$. Overall it can be said that meta-narratives about the economic crisis appeared linked

7 Results of a hierarchical cluster analysis. 
with those enhancing the necessary character of the EU accession and the dominant discourse was a utilitarian one. Disappointment with Hungary's EU membership often paired up with discourses on the need to belong somewhere. Similarly, disappointment with the political elite and corruption often appeared together and in the case of the Hungarian nationalistic discourses there were many allusions to the value crisis. Interestingly, and in a somewhat unexpected way, interviewees often mentioned that the accession primarly benefitted for the EU with the enlarged markets and were still enthusiastic about the EU overall - this result could be explained through the poor argumentation and lack of an elaborate opinion in case of positive attitudes. The poor argumentation could be a sign of less grounded opinions and could result in non-consistent and contradictory discourses on the matter. The Hungarian discourse and the value crisis both show a rather symbolic logic as previously mentioned just as the positive or "don't know" attitudes towards the EU. It seems that the lack of proper arguments made people turn to rather symbolic kinds of narratives. Nevertheless, in case of the utilitarian attitudes the range of the possible meta-narratives on the European Union and Europe was wider in expressing one's opinion. Besides, utilitarian and symbolic discourses can be very well differentiated in terms of the used meta-narratives and usually appeared in different interviews with each one a dominant, utilitarian or symbolic approach.

Table 2: Number of interviews where the different meta-narratives appear

\begin{tabular}{|c|c|c|c|c|}
\hline \multicolumn{2}{|c|}{ Meta-narratives: } & $\begin{array}{c}\text { Number of } \\
\text { interviews }\end{array}$ & $\begin{array}{c}\text { Type of the } \\
\text { meta-narrative }\end{array}$ & $\begin{array}{c}\text { The attitudes } \\
\text { towards the EU }\end{array}$ \\
\hline \multirow{3}{*}{ Economic } & World crisis & 19 & utilitarian & $\begin{array}{c}\text { positive/ } \\
\text { negative }\end{array}$ \\
\cline { 2 - 5 } & Globalization & 8 & utilitarian & - \\
\cline { 2 - 6 } & New market & 7 & $\begin{array}{c}\text { utilitarian/ } \\
\text { symbolic }\end{array}$ & $\begin{array}{c}\text { necessity/ } \\
\text { negative }\end{array}$ \\
\hline \multirow{3}{*}{ East-West } & East-West in general & 11 & $\begin{array}{c}\text { symbolic/ } \\
\text { utilitarian }\end{array}$ & positive \\
\cline { 2 - 6 } & $\begin{array}{c}\text { Bad attitudes of } \\
\text { people/ value crisis }\end{array}$ & 8 & symbolic & positive \\
\hline \multicolumn{2}{|c}{ Hungarian } & 7 & symbolic & - \\
\hline
\end{tabular}




\begin{tabular}{|c|c|c|c|c|}
\hline \multirow{2}{*}{$\begin{array}{c}\text { Domestic } \\
\text { political arena }\end{array}$} & Bad political elites & 8 & $\begin{array}{c}\text { symbolic/ } \\
\text { utilitarian }\end{array}$ & disappointed \\
\cline { 2 - 5 } & Corruption & 7 & $\begin{array}{c}\text { symbolic/ } \\
\text { utilitarian }\end{array}$ & disappointed \\
\hline \multirow{3}{*}{ Accession } & Need to belong & 6 & utilitarian & $\begin{array}{c}\text { pragmatic/ } \\
\text { positive }\end{array}$ \\
\cline { 2 - 5 } & We were unprepared & 5 & utilitarian & $\begin{array}{c}\text { pragmatic/ } \\
\text { positive/ } \\
\text { disappointed }\end{array}$ \\
\cline { 2 - 5 } & $\begin{array}{c}\text { Exclusivity is lost by } \\
\text { the expansions }\end{array}$ & 5 & $\begin{array}{c}\text { symbolic/ } \\
\text { utilitarian }\end{array}$ & $\begin{array}{c}\text { pragmatic/ } \\
\text { disappointed }\end{array}$ \\
\hline
\end{tabular}

\section{BEING EUROPEAN AND BEING HUNGARIAN}

One of this paper's aims is to determine whether people are rather linked to Europe and the European Union in a utilitarian or a symbolic way. One of the apects of this subject is involving identity, national and European identity and how they relate to each other. In the previous parts the cognitive attachment to the European Union was analyzed through its meaning and the different meta-narratives it appears in. In this current part of the paper the emotional attachment or identification with Europe and the EU will be in the focus. Several times in the interwiews the situational or contextual character of identification with Europe or the European Union came up. Respondents mentioned that talking about this would make sense from a non-European aspect, or from a point of view from out of Europe.

As mentioned previously, in theories about identity there is a civic vs. cultural divide. This divide, with allusions to cultural contents on the one hand, and democracy and solidarity on the other hand also appears in the interviews with regards to European identity. The following extract is also a good example of the role of an outgroup, or a significant other in identityformation. Furthermore, people tried to avoid symbolic speeches or contents regarding Europe and the European Union, sometimes they even mentioned this explicitly.

„.... For me, the essential is to have a calm and peaceful life without wars and aggression. If this is what Europe stands for, I can imagine that. Peace... and the single duty to care about making life as good as possible for everyone with the smallest possible social differences, if things are going this way, then I could imagine a label 
such as European society. But right now I don't relate it to culture at all [...] I am more of a down-to-earth kind of person, and I don't like if even politicians have these elevated speeches... for me Europe doesn't mean anything in the sense it is usually referred to as the ancient continent... or European style of whatever, in contrast with the USA... because Europe is usually contrasted with the USA... contrasting it with Asia the differences would be certainly more marked... or Africa... So for me Europe is a geographical notion and I usually don't attach nothing else to it... no big ideas. So... if things like democracy, humanism, or so are attached to it, then it's $O K$, then that could be the meaning of Europe. But my problem is that I'm more pessimistic... and I think that these things hold until there are political and economic interests behind." (40-49 year old man with university education)

As opposed to the civic way of identification, the cultural or ethnosymbolical elements of European identity are rather missing from the discourses, furthermore, there are explicit allusions for the lack of it. According to an essentialist conception of European identity (see Anthony Smith) the EU is conceived as a European family where all nations preserve their own culture.

„I'm not against the European Union - and a community might have something that holds them together, people with the same ideology form a stronger group. So I support this in any case, but it shouldn't be at each other's expense, they should keep their own identity. So the European should be a great community but not a melting pot. Like at school, it is a community, but everyone is different, in the European Union every country is different. And this should be respected. I think that the diversity is nice and it could be working..." (31 year old man with university education)

At the same time, the attachment to the European Union, the pride of being a citizen of European Union is also present in the discourses, but linked with an idea of a federalistic EU. Nevertheless, the need for an emotional attachment or the idea of such things comes up several times.

,I would like to see that one is able to say I'm proud of being a citizen of the EU... An American can say that I'm a citizen of the USA. So the EU project will be complete when you, or he or she will be able to say that I'm Hungarian, but I'm also the citizen of the United Europe. This is where we have to get." (64 year old man with university education) 
Analyzing the link between national and European identity, whether they are strengthening each other or excluding each other the main finding is that usually people think that just by being Hungarian they are already European. However, they attribute different importance to their Europeanness and still conceive Europe as a geographical unity.

„As I already told, I was already feeling European because we are living in Europe, so I felt that way, it didn't change, I haven't thought about it. I don't think about me being a European. If you ask me, yes, I live in Hungary and Hungary is in Europe, so I'm European. That's it. That's it for being a European... So summing it up I can only tell you that I can say that I'm a European if I look at the map. Because I live in Europe, Hungary is in Europe. But whether it makes me feel somehow, it doesn't make me feel either good or bad." (50-59 year old man with technical education)

Several times there is a hierarchical order between the attachment to different territorial levels (Hungary/ Central Europe/ Europe) and the ranking is made explicit in the interviews. These discourses confirm the conception of identity as concentric circles where the different levels are not excluding each other but are built on each other in a certain way (e.g. Bruter 2005). In some cases, however, according to the some previously described empirical findings (e.g. Carey 2002), Europeanness appears as opposed to being Hungarian.

Table 3 sums up the different kinds of the personal identification with the EU or Europe present in the interviews. It can be seen that being Hungarian and being European are excluding each other only in a few cases, whereas Europeanness rather appears as a condition, concomitant with being Hungarian, in some cases appear in a hierarchical order, as something of secondary importance.

The discourses about Europe as a family of cultures usually are complementing the utilitarian discourses on the European Union. In case of the EU integration a unification process is acceptable, but this doesn't hold for Europe in the cultural sense. 
Table 3: Occurrence of the different forms of identification with Europe in the 20 in-depth interviews

\begin{tabular}{|l|c|}
\hline Total: & 20 \\
\hline I'm Hungarian, so this way I'm European too & 7 \\
\hline Concentric circles (being Hungarian is more important than being European) & 6 \\
\hline EU citizenship: emotional attachment & 5 \\
\hline Europeanness has no symbolic meaning & 4 \\
\hline European family & 4 \\
\hline Europeanness: contextual, situational character & 3 \\
\hline Europeanness: civic aspects, solidarity, peace & 3 \\
\hline Being European <-> being Hungarian & 3 \\
\hline
\end{tabular}

\section{MAIN FINDINGS}

The main aim of this paper was to assess other studies on the subject, mainly with a quantitative approach, with insights on how Hungarian people define the concepts of Europe and European Union, what could they have in mind when answering survey questions and how do they relate to the European Union when they have the possibility to express their opinion freely, without the constraints of a questionnaire with pre-elaborated questions and answers.

In line with the results of previous studies with a quantitative approach (e.g. McLaren 2006) people in Hungary are indeed more open to a utilitarian/ pragmatic approach of the subject of the European integration, and regarding Europe the majority of the discourses were not symbolic as expected, but pragmatic too. However, those who couldn't tell much about the topic were more likely to hold a discourse about European values and history and, this way, were also more positive towards the EU than those weighing utilitarian arguments. As opposed to this, those who had a well-elaborated opinion on the subject, could cite concrete examples, were weighing advantages and disadvantages which led to a pragmatic/ utilitarian discourse. These results place the outcome of previous quantitative studies in a different light (Lengyel-Göncz 2006, 2009, 2010). In these studies the main argument was that although Hungarian public opinion is not very positive towards the EU in utilitarian terms, the symbolic attachment to it is still above the EU average according to these results it seems that symbolic attachment is rather defined by the lack of well-grounded opinions, while the utilitarian approach remains the relevant frame for the attitudes.

Most of the interviewees evaluated Hungary's EU membership as a 
necessity or unavoidable event. The discourses about the disppointment with the consequences of the accession compared to the previous expectations were also quite varied depending on the extent to which it appeared in conjunction with disappointment with the domestic economic and political performance. Therefore, results confirm that the evaluation of the EU is highly dependent on the evaluation of the domestic political arena (Anderson 1998, HoogheMarks 2005).

As for the concepts of Europe and the European Union the main outcome of the interviews was that these concepts are interchangeable and appear with a similar content in the discourses. However, when specifically asked for the difference between the two, people associated unity with the EU, while Europe rather appeared as a fragmented, multi-faceted entity. Europe is mostly conceived through references to geography. The European Union on the other hand is seen in a very utilitarian way through its advantages and disadvantages and it is attributed richer content than the different conceptions of Europe. This, however, can be due to the role of the media where the utilitarian approach of the European Union was more intensively present than any allusions to Europe.

Meta-narratives on Europe and the European Union are diverse. The economic, pragmatic approaches are very typical through the process of the accession, placing the subject in an East-West narrative, or in the context of Hungarianness. Most of the meta-narratives found contain both utilitarian and symbolic elements, although utilitarianism dominated the discourses. In some cases symbolic contents are explicitly refused. Anyhow, the main experience of these interviews is that the subject of the European Union and Europe represents an important cognitive challenge for the people, interviewees usually did not have a well-grounded opinion; they were often formulating it on the spot for the first time during the interview that often led to inconsistencies. These inconsistencies could be an interesting subject for further research.

\section{REFERENCES}

Anderson, Christopher J. (1998): "When in doubt, use proxies". Comparative Political Studies, vol. 31, no. 5, pp.569-601

Bruter, Michael (2005): Citizens of Europe? The Emergence of a Mass European Identity, Palgrave, Macmillan

Carey, Sean (2002): "Undivided Loyalties. Is National Identity Obstacle to European Integration?" European Union Politics 3 (4), pp.388-413 
Cichowski, Rachel (2000): "Western Dreams, Eastern Realities: Support for the European Union in Central and Eastern Europe". Comparative Political Studies, vol. 33, no. 10, pp. 243-1278

Delanty, Gerard (1995): Inventing Europe: Idea, Identity, Reality, New York, St.Martin's Press

Gabel, Matthew (1998): "Public Support for European Integration: An Empirical Test of Five Theories". The Journal of Politics, Vol.60, pp.333-354

Göncz, Borbála (2009): "Deliberated opinions and attitudes on the EU". In: Lengyel, György (ed): Deliberative Methods in Local Society Research. Új Mandátum Kiadó, Budapest

Hooghe, Liesbet - Marks, Gary (2005) "Calculation, Community and Cues. Public Opinion on European Integration", European Union Politics, Volume 6 (4), pp.419-443.

Inglehart, Ronald (1970): "Cognitive Mobilization and European Identity". Comparative Politics Vol. 3, No. 1

Isin, Engin Fahri - Wood, Patricia K. (1999): Citizenship and Identity, Sage Publications

Janssen, Joseph I. H. (1991): "Postmaterialism, Cognitive Mobilization and Support for European Integration”. British Journal of Political Science 21, pp.443-468

Lengyel György - Göncz Borbála (2006): "Symbolic and pragmatic aspects of European identity”. Sociologija, Vol. XLVIII., no.1: 1-17.

Lengyel György - Göncz Borbála (2009): "Elites' Pragmatic and Symbolic Views about European Integration”. Europe-Asia Studies, Vol 61. No. 6, pp.1059-1077

Lengyel György - Göncz Borbála (2010): “A magyar EU-tagság a közvéleményben” [The perception of Hungarian EU-membership in Hungarian public opinion] Társadalmi Riport 2010, TÁRKI, pp. 527-547

Mason, Jennifer (2002): Qualitative Researching. London, Sage Publications

McLaren, Lauren M. (2006): Identity, Interests and Attitudes to European Integration, Basingstoke, Palgrave Macmillan

Melegh, Attila (2006): On the East/West Slope. Globalization, Nationalism, Racism and Discourses on Central and Eastern Europe. New York-Budapest, CEU Press

Optem S.A.R.L. (2001): Perception of the European Union. A qualitative study of the public's attitudes to and expectations of the European Union int he 15 member states and in 9 candidate countries. Summary of results. http://ec.europa.eu/public opinion/quali/ql_perceptions_summary_en.pdf(acessed: 2009.03.22)

Pahl, Ray (1995): After Success. Fin-de-siecle Anxiety and Identity. Cambridge, Polity Press

Patton, Michael Quinn (1990): Qualitative Evaluation and Research Methods. London, Sage Publications

Seidman, Irving (2006): Interviewing As Qualitative Research: A Guidefor Researchers in Education and the Social Sciences. London: Teachers College Press

Smith, Anthony D. (1991): National Identity, London: Penguin Books

Smith, Anthony D. (1992): "National Identity and the Idea of European Unity", International Affairs 68(1), pp.55-76 
Tardos, Róbert (2004): “Tudás (és nem tudás) az EU-ról: ismeretek, tapasztalatok, külső beágyazottság" [Knowledge (and the lack of) about the EU: information, experiences, external embeddedness]. JEL-KÉP 2004/4, pp.13-32

Terestyéni, Tamás (2004): “Az Európai Unióval kapcsolatos közérdeklődés”. [Public interest about the EU] JEL-KÉP 2004/4, pp.53-70

Tucker, Joshua A. - Pacek, Alexander C. - Berinsky, Adam J. (2002): "Transitional Winners and Losers: Attitudes Toward EU Membership in Post-Communist Countries". American Journal of Political Science, July 2002

Vidra, Zsuzsanna (2006): “Az EU reprezentációja a magyar médiában a csatlakozási folyamat alatt", [Representation of the EU in Hungarian media during the accession period] 45-70, In: Hegedüs I. (ed.): A magyarok bemenetele. Tagállamként a bövülö Európai Unióban. DKMKKA, Budapesti Corvinus Egyetem, Politikatudományi Tanszék 